February 2022

\title{
An assessment of implementing green HRM practices on environmental performance: The moderating role of green process innovation
}

\author{
Foad Irani \\ Eastern Mediterranean University, foad.irani@emu.edu.tr \\ Hasan Kilic \\ Eastern Mediterranean University, hasan.kilic@emu.edu.tr
}

Follow this and additional works at: https://digitalcommons.usf.edu/jght

Part of the Hospitality Administration and Management Commons, and the Human Resources

\section{Management Commons}

This Refereed Article is brought to you for free and open access by the M3 Center at the University of South Florida Sarasota-Manatee at Digital Commons @ University of South Florida. It has been accepted for inclusion in Journal of Global Hospitality and Tourism by an authorized editor of Digital Commons @ University of South Florida. For more information, please contact digitalcommons@usf.edu.

\section{Recommended Citation}

Irani, F., \& Kilic, H. (2022). An assessment of implementing green HRM practices on environmental performance: The moderating role of green process innovation. Journal of Global Hospitality and Tourism, 1(1), 16-30. https://www.doi.org/10.5038/2771-5957.1.1.1001

Corresponding Author

Foad Irani, 99628, Famagusta, North Cyprus, Mersin 10, Turkey

Revisions

Submission date: Nov. 9, 2020; 1st Revision: May 5, 2021; Acceptance: May 18, 2021 


\title{
An Assessment of Implementing Green HRM Practices on Environmental Performance: The Moderating Role of Green Process Innovation
}

\author{
Foad Irani ${ }^{1}$ and Hasan Kiliç ${ }^{2}$ \\ Faculty of Tourism \\ Eastern Mediterranean University, North Cyprus \\ ${ }^{1}$ foad.irani@emu.edu.tr \\ 2hasan.kilic@emu.edu.tr
}

\begin{abstract}
As the world is trying to curb $\mathrm{CO}_{2}$ emission, mainly from the industries, various organizations' employees are crucial in mitigating carbon monoxide emissions. The employee reaction based on their perception of human resources management practices shapes their commitment to the workplace environment. According to relevant environment literature, emphasizing effective environmental management improves employees' green attitudes dedicated to natural purposes. This study explores how to enhance hotels' environmental performance (EP) by adopting green human resource management (HRM) practices. The current study developed and investigated a moderation model which examined the green process innovation (GPI) as a moderator onto the relationship between green HRM and environmental process through the lens of AbilityMotivation-Opportunity theory (AMO). SmartPLS software was used to analyze the data from 220 full-time employees of 3-, 4-, and 5-stars green hotels in Turkey. The findings demonstrate the importance of adopting green practices in advancing organizational performance, especially the environmental aspect. The novel findings of this study enrich the moderation effect of GPI in hospitality literature.
\end{abstract}

Keywords: green HRM, GPI, EP, green hotels, AMO theory, Turkey

\section{Introduction}

The exponential development of the industry is contingent on natural resources, which causes environmental destruction (Bhatti et al., 2020; Irani et al., 2021; Rusinko, 2007; Ozdemir et al., 2021). Several countries have introduced environmental legislation to conserve and minimize greenhouse emissions by limiting energy usage; for example, the chlorofluorocarbon, the Johannesburg World Summit Sustainable Development Notices, and prohibitions on other dangerous substances (e.g., ban on electric and electrical devices, EU limitation on hazardous substances). This sort of legislation not only increased environmental conservation awareness, but it also enhanced corporate management practices and competitiveness. To conform with existing environmental regulations, organizations were required to adopt environmentally sustainable activities. That is to say; they can follow initiatives and policies that enable them to paradoxically boost their brand identities while still supporting sustainable growth to thrive in the competencies. (Athari et al., 2020; Irani \& Rahimizhian, 2021; Panwaret, 2011; Qi et al., 2010). Going green was one of the primary ways in which organizations discussed environmental issues. Over the past 
decades, methods for improving green technologies and sustainability policies have piqued the public's imagination and stimulated debate (Davis, 1995; Schiederig et al., 2012). To promote green technologies, organizations must recognize the essential factors and antecedents of their industries (Hadiet al., 2020; Routroy, 2009). They involve customer demands, organization owners' interests, producer capacities, government policy, and the fiscal, organizational, and antecedents that improve the atmosphere by pro-environmental measures. The impacts of different determinants on green actions have received attention in the relevant literature. However, the antecedents of implementing GPI have received less attention in a relevant context (Weng et al., 2015). Furthermore, it is essential to pay closer attention to the effect of each stakeholder in an organization on developing green innovation capacities and activities.

Top hierarchy management is involved in recognizing what the critical factors in developing innovative green activities are. In contrast, much of the prior research has concentrated on the manufacturing field or a single business area (Park \& Park, 2020). It would be helpful if a general blueprint were included to tackle concerns relevant to innovation in green activities for the sector. Organizational environmental management strategies depend on the development and maintenance of internal competencies and capacities (Mercan et al., 2020; Yin \& Schmeidler, 2009; Yong et al., 2019), whereby small and medium-sized companies were found to be significant defaulters due to a lack of employee expertise and enthusiasm combined with the organizational resources needed to tackle complex sustainability toward environmental challenges (Ali et al., 2020; Biscotti et al., 2018; Boiral et al., 2014; Russo, 2009).

This study contends that green HRM practices are focused on improving the business's internal competencies and skills, which are essential for managing people in small and medium-sized enterprises (SMEs) with specific points of view (Leroy et al., 2018). Simultaneously, previous research indicates that employees' role in corporate culture and the psychological characteristic of employees determines the success of SMEs (Brettel et al., 2015; Elsetouhi et al., 2018; Palmer et al., 2019). Nonetheless, we prescribe green HRM practices which help during the procedures, impact employee on a larger scale in an organized manner would be the manner for enhancing GPI and EP in SMEs, especially in a relatively power-distance society like Turkey (AlMazrouei et al., 2016; Lievens, 2015).

Predominantly, the current research primarily intended to address this gap by exploring how green HRM practices result in decisive consequences, such as green hotel environmental success. The green HRM practices examined in this study at the individual level. This empirical study's main objective is to understand better how to enhance EP by investigating the role of green HRM practices. To address this objective, the study examines the association between green HRM practices and EP and the moderating role of GPI towards the effects of green HRM practices on EP. Instead, this study analyzes the process that green HRM practices contribute to significant results, specifically EP, at green hotels. The findings of this study analysis confirmed the hypotheses. By undertaking a structural equation modeling using the partial least squares path modeling method research approach, this study contributes to the existing relevant context in three ways. First, by creating a positive association between green HRM practices and EP, this study tries to demonstrate a situation that can contribute to the appropriation of green HRM practices beyond harsh administration discipline. Second, focusing on the AMO, the study advances current literature on green HRM activities at the individual level. Third, the study sheds light on the 
framework by which green HRM practices affect employee outcomes by taking into account the crucial role of GPI as a moderator in the intended model.

\section{Literature Review}

\section{Theoretical Framework}

The AMO theory is widely applied in diverse disciplines, particularly in the HRM context (Boselie et al., 2005). The AMO theory's potential is identified to enhance organizational employees' behavior, contributing to the organization's performance (Appelbaum et al., 2000). Based on the literature review results, the AMO comprises collective interests and willingness to research an individual's actions in the light of sustainability toward organizational development (Marin-Garcia \& Tomas, 2016). A variety of studies have examined green HRM practices in different sectors (i.e., Pham et al., 2019; Pinzone et al., 2016; Singh et al., 2020; Yu et al., 2020). The AMO theory has been used in various studies to explain the contributions of green HRM practices on EP, but there is a lack of adequate studies that employed the AMO framework in their studies (Anwar et al., 2020; Ragas et al., 2017).

The integration of green HRM practices and environmental protection systematically shapes a new avenue to implement remunerative management options that benefit managers, workers, customers and businesses, and other stakeholders in the organization (Jackson et al., 2011). When stakeholders coordinate their efforts to promote environmental sustainability, and the process is built on partnerships focused on equal sharing, a win-win system occurs (Gursoy \& Kendall, 2006; Mitchell \& Jolley, 2012). According to a recent finding derived from a related environmental literature analysis, individuals who see a boost from environmental conservation are more inclined to contribute back by seizing chances to improve organizational EP (Temminck et al., 2015). The position of green HRM practices received less recognition. In contrast, previous studies in broader management literature have demonstrated, by adopting AMO theory, that green HRM behaviors, combined with support from organizations, put up personal motivation to compensate for the admiring interest of the managers of organizations in the sense of environmental growth (Cheema \& Javed, 2017; Tremblay et al., 2010).

\section{Green Human Resource Management (HRM) Practices}

The green HRM initiatives are described as innovations, policies, and the procedures in which organizations imply to reduce the negative impacts and simultaneously increase the positive impacts on the environment (Arulrajah et al., 2016; Kim et al., 2019). That is to say; green HRM practices is to train employees who are capable of adopting pro-environmental behaviors toward the environmentally sustainable development of their organizations. Therefore, various actions form an organization's human capital, such as recruiting applicants with green attitudes, training, green empowerment, and reward (Arulrajah et al., 2016; Irani et al., 2020). Green HRM practices are among the most critical determinants in an organization striving toward environmentally sustainable practices that motivate employees (Ren et al., 2018).

Recently, the work process of the HRM system made headway to new forms in which the employee's involvement level increased in more participation and support approaches (LengnickHall et al., 2009; Masri \& Jaaron, 2017), which result in opportunities to adopt skills, knowledge, 
and attitudes by the employees (Singh et al., 2019). In a period of risen understanding of environmental sustainability and natural resource development, green human resources management corresponds to HRM activities aiming at the environment and economic implications of organizations (Roos \& O'Connor, 2015) and is related to a coherent environmental approach and green behavior of employees (Cavicchi, 2017; Renwick et al., 2013; Yusoff et al., 2020). The study contends that green HRM practices are crucial for HRM literature centers on efficient natural administration applications (Dumont et al., 2017). Wherever green HRM attends as a tool to correlate human resource practices to the organizational environment's administration actions.

\section{Green Process Innovation (GPI)}

Green innovation is defined as a procedure to develop environmentally sustainable products and services by conducting actions that help conserve the environment the adverse effects through replacing greener raw materials and renewable energies with conventional procedures (AgyabengMensah et al., 2020; Albort-Morant et al., 2018). Different research emphasized that organizations with a higher level of innovation in green activities obtain better overall performances than other competitors, leading them to achieve competitive advantages (Albort-Morant et al., 2016; Allameh \& Khalilakbar, 2018; Rahimizhian \& Irani, 2020). Green innovation is related to the organization's strategy for environmental sustainability. Green innovation improves EP in turn, greener product and process advancement not only decrease the organization's adverse environmental effects and also enhance the social and economic aspects of the organization by minimizing waste and costs (Agyabeng-Mensah et al., 2020; Luu, 2019; Weng et al., 2015).

\section{Environmental Performance (EP)}

The EP involves organizational programs intended to fulfill and surpass public standards of the natural world in a way that goes beyond pure compliance with laws and regulations (Arda et al., 2019). It includes the impacts of the environment according to environmental requirements legislation (Dubey et al., 2015). Prior research indicates EP would rely on the quality of green goods, green technologies, and technological developments, and merging into company activities and product growth of sustainability toward environmental development (Darnall et al., 2008; Pham et al., 2020). EP is defined as protecting the environment (Paillé et al., 2014; Roscoe et al., 2019) through an organizational commitment by illustrating the importance of conserving the natural resources (Dubey et al., 2015).

\section{Green HRM Practices and EP}

The human resource department of organizations is critical to raise the benefits of the organization (Arulrajah et al., 2016), so it is apparent from previous studies that corporations are fostering effective environmental management policies, with the reduction in expenses and increase in profit channels, to achieve core environmental business objectives (Arda et al., 2019; Ogbeibu et al., 2020). Information suggests that green HRM activities are among the most potent approaches to enhancing organizations' environmental efficiency. They provide an essential framework to effectively minimize corporations' environmental footprint (Sudin et al., 2020). Green HRM practices, like environmentally sustainable HR operations, also contribute to enhanced efficiencies, reduced expenses, and strengthened employee participation and retention. This would help organizations reduce the carbon footprint of workers (Arda et al., 2019; Sheopuri \& Sheopuri, 
2015). The green HRM activities also help organizations develop their EP by the awareness of environmental issues among employees (Fayyazi et al., 2015). One of the appropriate approaches to promoting EP is adopting green HRM practices (Dutta \& Lanvin, 2012). The green HRM initiatives lead the organizations to have employees who are embodied in green thinking and attitudes. Employees are the foundations of their organizations so that their roles in conserving the environment are well known (Daily et al., 2009; Dutta \& Lanvin, 2012; Kim et al., 2019; Teixeira et al., 2016). The previous study supports developing a green HRM environment where employees view green projects and practices as expected values. This can point out the empowerment based on green attitudes aiding organizational EP results, enhancing employee engagement, and sustaining the green initiatives (Gholami et al., 2016; Nejati et al., 2017).

Jabbour and Santos (2008) exerted that green HRM practices have been shown to add substantially to organizations' sustainable success. Similarly, organizations that conducted green HRM activities and employed various employee layers in the program had good environmental results (Nejati et al., 2017; Paillé et al., 2014). The green HRM practices are seen as effective methods to boost human resources of the organizations that can potentially drive to improved EP through developing the green behaviors of the employees and promoting green organizational culture (Álvarez Jaramillo et al., 2019; Kim et al., 2019; Roscoe et al., 2019). The majority of the relevant context studies demonstrate the prominent role green HRM practices play in promoting environmental sustainability (Arda et al., 2019; Kim et al., 2019; O’Donohue \& Torugsa, 2016; Paillé et al., 2014). Daily et al (2009) exerted those green actions should be considered among various employees (i.e., personal, team, and organizational) at the workplace. Vidal-Salazar et al. (2012) focused on the importance of having a positive linkage between environmental training and organizational learning. Employees of environmental ideals are considered to have a vital role in promoting organizations proactively embrace and enforce concepts of environmental protection and improve the EP of an organization (Daily et al., 2009; Dutta \& Lanvin, 2012; Kim et al., 2019; Paillé et al., 2014; Teixeira et al., 2016). Therefore, the following hypothesis formed:

- H1: Green HRM practices positively influence the EP.

\section{Moderation of GPI}

Previous findings have shown that green HRM practices positively affect GPI (Jimenez-Jimenez \& Sanz-Valle, 2008; Wei et al., 2011). Green HRM practices targeted at improving an atmosphere of engagement rather than compliance positively impact the organization's creative direction (Das et al., 2018). Likewise, strategic green HRM practices enhance the GPI of the organizations, which develops the organizational structure (Wei et al., 2011). Meanwhile, previous studies relevant to HRM innovation have received less attention among scholars and practitioners (Bos-Nehles \& Veenendaal, 2019). Furthermore, integrated findings on the association between green HRM and innovation in green processes at organizations are scarce. By utilizing AMO, this study intercepts that to provide and enhance the determinant that fosters the opportunities to green human resources are required to imply the green innovations into the entire organizational sectors.

- H2: GPI moderates the association between green HRM practices and EP. 
Figure 1. Proposed Model

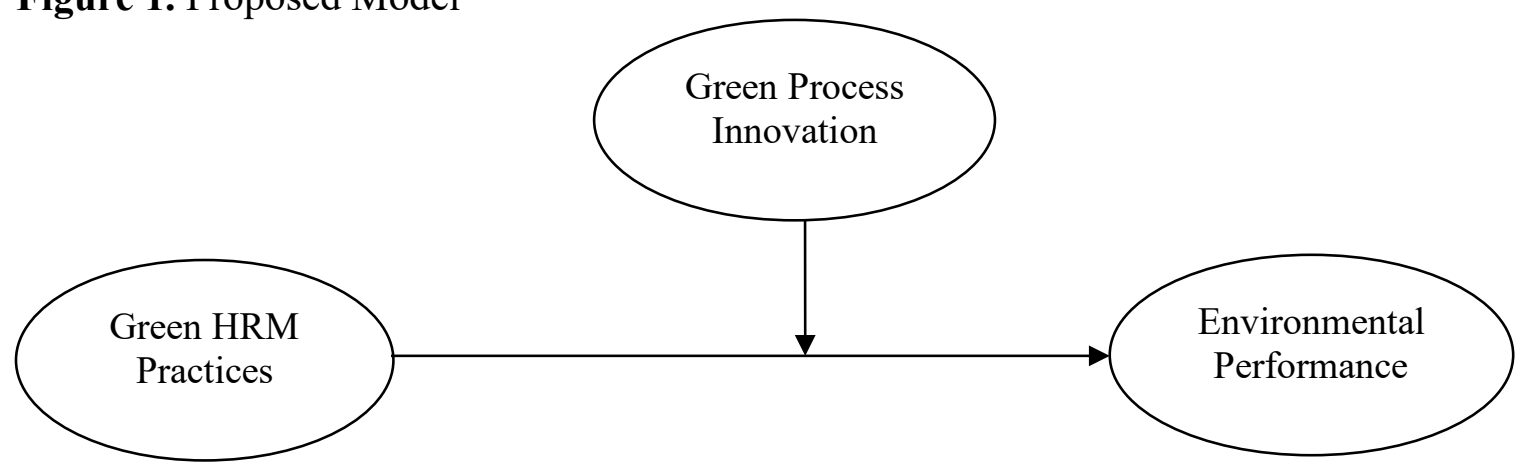

\section{Methods}

\section{Procedure and Sample}

The proposed hypothesis was developed based on extant literature and tested based on data gathered from Turkey's green hotel employees. Turkey stands among the top ten tourist countries with different attractions (UNWTO, 2020). The list of Turkey's green hotels was extracted from the green globe institution (www.greenglobe.com). The green members are committed to applying organizational management to foster sustainability development, replacing the conventional fossil fuels with renewable energies, financial investment regarding environmental conservation activities, and proactive employees' involvement and motivating them to be engaged in proenvironmental initiatives. The green globe received UNWTO affiliation, and the sustainable tourism standards are based on the global sustainable tourism council. There are seven green hotels in Turkey, according to the green globe institution. There are four 5-stars green hotels, two 4-stars green hotels, and one 3-stars green hotel. The research team approached the aforementioned green hotels' HRM with a letter, including the aim and permission request for data collection. As such, the seven green hotels' HRM agreed to contribute to this empirical study.

Furthermore, phase distinction was used in this empirical study by collecting data in two different periods with the interval of 14 days between the measurement scales to minimize the potential common method bias, which can devalue the correlations between the study variables (Podsakoff et al., 2003). Thus, two detached questionnaires were used for this survey study (e.g., phase I and II). The independent and moderator variables formed phase I and phase II was included by the dependent variable and the demographic variables. The purpose of the research was clarified to the participants after permission was granted. The participants were invited to participate as volunteers, and the study team ensured their anonymity (Hair et al., 2014). The questionnaires were filled out using a self-administrated technique and were collected sealed in separate envelopes. Those questionnaires in unsealed envelopes were discarded, and only the sealed envelopes were considered in this study (Cobanoglu et al., 2021).

Two hundred thirty-six questionnaires were distributed to employees of green hotels and resorts in Turkey. The green hotels of Turkey have been selected as the intended sample due to the high contribution of Turkey as it ranked among the first high ten countries of tourist arrivals according to UNWTO from 2020 report. A total of 236 questionnaires was distributed, the collected copies were 223 , and 220 of the questionnaires were usable. The majority of the participants were male by one hundred and fourteen $(51.8 \%)$, and the rest were female. The majority of the participants, 
with one hundred and twenty-four (56.4\%) aged between 28 and 37. Approximately half of the respondents (48.9\%) had a bachelor's degree. The organizational tenure of $31.5 \%$ of the respondents was between 1 to 5 years.

\section{Measures}

The 5-points Likert scale ranging from 1 strongly disagree to 5 strongly agree were used to measure the variables. To ensure reliability and validity, the measuring items were adapted from existing literature. The green HRM practices were measured by slightly adapting eight items (Shafaei et al., 2020). These items measured the extent of employees' actions regarding environmental issues. GPI was measured by three items slightly adapted from existing literature (Singh et al., 2020). These items measured the extent of the hotel's policy by reducing energy usage. The EP was measured by five items slightly adapted from previous studies (Singh et al., 2020). These items assessed decreases in hazardous waste and pollution, concentrations of scrap, and improved awareness about legislation. The original version of the items (e.g., phase I and II) was in English. Since the aim was to collect data from employees of green hotels located in Turkey, the original version translated to the Turkish language as it is the official language of Turkey. The questionnaire's back-translation has been done using two independent multilingual experts who are fluent in English and Turkish languages (Parameswaran \& Yaprak, 1987; Schaufeli et al., 2006).

\section{Results}

\section{Validity and Reliability of the Data}

The constructs' internal consistency and reliability are illustrated in Table 1; the Cronbach's alpha and composite reliability threshold must be over .70 (Hair et al., 2014; Nunnally \& Bernstein, 1994). Thus, the measure items of this study meet the criteria of being reliable. The average variance extracted (AVEs) and outer loadings measured by using Smart PLS.

Table 1. Results of Confirmatory Factor Analysis

\begin{tabular}{lcccc}
\hline Items & Outer Loadings & Cronbach Alpha & CR & AVEs \\
\hline Green HRM Practices & & .91 & .92 & .61 \\
Green HRM1 & .67 & & \\
Green HRM2 & .84 & & \\
Green HRM3 & .86 & & \\
Green HRM4 & .83 & & \\
Green HRM5 & .79 & & \\
Green HRM6 & .74 & & \\
Green HRM7 & .72 & .84 & \\
Green HRM8 & .77 & & .90 \\
GPI & .80 & & .75 \\
GPI1 & .88 & & \\
GPI2 & .90 & & \\
GPI3 & & & \\
EP & .77 & & .65 \\
EP1 & .73 & & \\
EP2 & .81 & & \\
EP3 & .88 & & \\
EP4 & .81 & & \\
EP5 & & & \\
\hline$N$
\end{tabular}

Note. HRM = Human Resource Management, GPI = Green Process Innovation, EP = Environmental Performance, CR: Composite Reliability, AVEs: Average Variance Extracted 
The convergent validity of this study's data was confirmed since the AVEs, and outer loading was above .50 (Hair et al., 2014). Therefore, as shown in Table 2, the Heterotrait-Monotrait (HTMT) values of the constructs were measured and obtained less than .90 (Henseler et al., 2016). Therefore, discriminant validity seems to be in the required criteria.

Table 2. Result of Heterotrait-Monotrait Ratio (HTMT)

\begin{tabular}{lccc}
\hline Constructs & Environmental Performance (EP) & Green HRM Practices & Green Process Innovation (GPI) \\
\hline Green Human Resource & 0.4042 & & \\
Management Practices & & & \\
GPI & 0.2042 & 0.6087 & 0.4556 \\
EP & 0.1123 & 0.3102 & \\
\hline
\end{tabular}

\section{Assessment of the Structural Model}

The moderation that is to measure and assess the differential effect of the independent variable on the dependent variable based on Baron and Kenny (1986) approach was applied. The Smart PLS tests the direct relationship between green HRM practices as an independent variable and EP as a dependent variable and the moderation effect of GPI on the association between the direct relationship between green HRM practices and EP. Table 3 represents the results of the hypothesis testing of this study model. To examine and compare the importance of path values, this research employed the Smart PLS technique with standard bootstrapping of 5000 samples and 220 cases (Hair et al., 2014).

Table 3. Structural Model Assessment With Moderation

\begin{tabular}{lcccccc}
\hline Hypotheses & $\boldsymbol{B}$ & $\boldsymbol{M}$ & $\boldsymbol{S D}$ & $\boldsymbol{T}$-Value & $\boldsymbol{P}$-Value & Status \\
\hline Green HRM Practices -> EP & 0.44 & 0.44 & 0.05 & 7.44 & .0000 & Supported \\
Moderating Effects -> EP & 0.27 & 0.27 & 0.07 & 3.99 & .0001 & Supported \\
\hline Note.
\end{tabular}

Note. $\mathrm{HRM}=$ Human Resource Management, EP = Environmental Performance

\section{Moderating Effect of GPI}

The GPI is a moderator variable in this study. The GPI is expected to have a positive influence on the association between green HRM practices and EP. Therefore, the findings revealed that GPI strengthens the link between green HRM practices and EP. By using Smart PLS at 5000 samples, and the bootstrapping approach, the moderating effect of GPI was assessed (Hair et al., 2019). As shown in Table 3, the interaction positively influences EP (0.27) while the green HRM practices' simple effect on EP is (0.44). The findings showed that the average level of green HRM practices toward the dependent variable is 0.44 . The size of the interaction term adds or distracts the link between green HRM practices and EP. For the more eminent levels of GPI, the one standard deviation unit adds to interaction term size (i.e., $0.44+0.27=0.71$ ). By distracting the one standard deviation unit from interaction term size (i.e., $0.44-0.27=0.17$ ), the bond between green HRM practices and EP becomes more inadequate.

By using Smart PLS, for interpreting the moderation finding, the simple slope analysis was used. The simple slope plot is illustrated in Figure 2 for more details regards moderation analysis. The positive slope for all three lines indicates the positive significance of green HRM practices on EP. Additionally, higher levels of green HRM practices increase the level of EP positively. All three lines (green, blue, and red) represent the GPI as a moderator that a higher level of moderator increases the level of green HRM practices and EP. In case of a decrease in GPI level as a moderator, the level of green HRM practices and EP decreases, respectively. 
Figure 2. Simple Slope Analysis of GPI

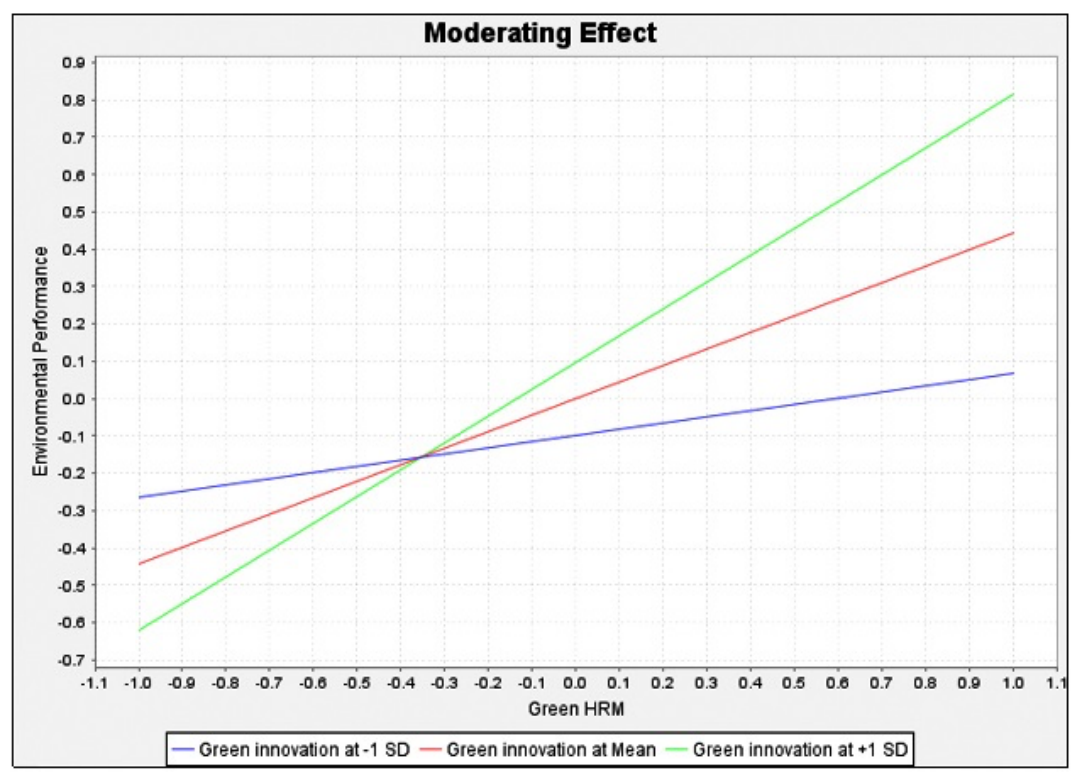

\section{Discussion and Conclusions}

This study addresses the main challenge in green innovation from the individual level, namely employees. This study aimed to explore the impact of GPI as a moderator on the association with green HRM practices and environmental processes. Green hotels, an emerging global challenge, has pushed hotels to constantly develop their sustainability capacity and adopt innovative green practices to protect the environment and enhance business results (Longoni \& Cagliano, 2018). The collective green HRM practices variable gives a comprehensive recognition of how green HRM practices and business impacts are interrelated (Anwar, 2018). The findings revealed a strong and positive influence of the green HRM practices on EP and a moderation effect of GPI on the relationship between the green HRM practices and EP.

\section{Theoretical Contributions}

There are several theoretical contributions as a result of this study. Firstly, this study findings strengthen AMO's perspective on the link between green HRM practices and the organization's EP (e.g., Anwar et al., 2020; Teece, 2014). Therefore, due to the growth of environmental awareness among the variety of stakeholders, this study findings explore the necessities of organization's key competencies, namely, green HRM practices and its implementation through employee's GPI (i.e., skills, knowledge, and attitudes) enhance the EP (Anwar et al., 2020; Chang, 2011; El-Kassar \& Singh, 2019; Teece, 2014). This study contributes to broadening the AMO framework concept and suggests that hotels can improve their EP by adopting green HRM practices. Previous studies confirmed the findings of this study as implementing the AMO framework is required to shape the association throughout the organizations by enacting the employee's abilities to be involved in seizing opportunities to enhance the EP (e.g., Anwar et al., 2020; Bhatti et al., 2020; El-Kassar \& Singh, 2019; Jabbour et al., 2019; Pham et al., 2020; Umrani et al., 2020). Thus, the findings confirmed that green HRM practices promote the EP through GPI (e.g., Chang, 2011; Jabbour et al., 2019; Luu, 2019). Thereby, the organization's green HRM practices are the backbone for intensified environmental management at the workplace. 
Finally, the purpose of adopting green HRM practices toward environmental activities is theoretically promoted, which is in line with former studies (e.g., El-Kassar \& Singh, 2019; Jabbour et al., 2019). Besides, in comparison with the study of Singh et al (2020), which suggests that GPI acts as a mediator between green HRM practices and EP, this study concentrated on GPI by hypothesizing it as a moderator. The findings support the claims that support the H2. Green thinking is a trend endeavor to straighten different organizations' HRM practices (Jabbour et al., 2019; Renwick et al., 2013; Singh \& El-Kassar, 2019). This study advises that green HRM practices play a notable task in reducing pollution reduction, product/service quality improvement, and enhancing the organizations' brand images. That is to say; this study implies that green HRM practices intensify the environmental management goals of the organizations by applying the GPI. The results also represent that GPI can strengthen the positive impacts of green HRM practices on EP, shedding light on the contingent approach that GPI improves EP.

\section{Practical Implications}

This research has some significant strategic consequences for tackling heightened environmental tensions, as they cannot continue to disregard core stakeholders' environmental concerns. Firstly, the organizations pursued approaches that enhance sustainable environmental development to reduce adverse effects (Hadood \& Irani, 2020; Longoni \& Cagliano, 2018; Yu et al., 2017). Thus, organizations should prioritize GPI to improve their EP, mainly when there are resource constraints. Secondly, organizations should invest in green HRM practices and establish new strategic assets compatible with environmental management initiatives. The findings pointed out that green HRM practices reflect the organizations' strategic orientations toward environmental protection and motivate them to exhibit eco-friendly activities.

Furthermore, we believe that green HRM practices need a developmental culture and a flat organizational environment to foster and boost green innovation and gain a long-term competitive advantage. Finally, the findings intimate that organizations should recruit employees who meet the organizations' criteria toward sustained proactive environmental management practices which result in environmental protection. Moreover, this study suggests that higher-level executives should affirm a system assessment to evaluate the employee's pro-environmental behaviors at workplaces and recognize and value the employees who are embedded in conserving the environment. That is to say; the green HRM practices should be inspired by the employees who are well-known as agents to implement the organizations' strategies.

\section{Limitations and Further Research}

This study is not without limitations as well as other studies. Firstly, the perceptual measures based on the extant literature were used in this study. In further studies, the objective measure can complement the perceptual measures simultaneously to advance the results. Secondly, GPI was used as a moderator to examine the influence of green HRM practices on EP. Future research should use other determinants such as capability, incentive, and contingency-based human resource practices to check whether they moderate the influence of green HRM practices on EP. Finally, the proposed model aimed the green hotels in Turkey. However, future research should test the proposed model in an expanded context to promote the theory and its implications. 


\section{References}

Agyabeng-Mensah, Y., Ahenkorah, E., Afum, E., Agyemang, A. N., Agnikpe, C., \& Rogers, F. (2020). Examining the influence of internal green supply chain practices, green human resource management and supply chain environmental cooperation on firm performance. Supply Chain Management: An International Journal, 25(5), 585-599.

Albort-Morant, G., Leal-Millán, A., \& Cepeda-Carrión, G. (2016). The antecedents of green innovation performance: A model of learning and capabilities. Journal of Business Research, 69(11), 4912-4917.

Albort-Morant, G., Leal-Rodríguez, A. L., \& De Marchi, V. (2018). Absorptive capacity and relationship learning mechanisms as complementary drivers of green innovation performance. Journal of Knowledge Management, 22(2), 432-452.

Ali, A., Rasoolimanesh, S. M., \& Cobanoglu, C. (2020). Technology in tourism and hospitality to achieve sustainable development goals (SDGs). Journal of Hospitality and Tourism Technology, 11(2), 177-181.

Allameh, S. M., \& Khalilakbar, R. (2018). Exploring the antecedents of innovation performance: The roles of entrepreneurial orientation, learning orientation and organisational learning. International Journal of Business Excellence, 14(4), 470-485.

AlMazrouei, H., Zacca, R., Bilney, C., \& Antoine, G. (2016). Expatriate managers decision-making practices within the UAE: A qualitative study. International Journal of Organizational Analysis, 24(5), 856-882.

Álvarez Jaramillo, J., Zartha Sossa, J. W., \& Orozco Mendoza, G. L. (2019). Barriers to sustainability for small and medium enterprises in the framework of sustainable development-Literature review. Business Strategy and the Environment, 28(4), 512-524.

Anwar, M. (2018). Business model innovation and SMEs performance-Does competitive advantage mediate? International Journal of Innovation Management, 22(7), 1-31.

Anwar, N., Mahmood, N. H. N., Yusliza, M. Y., Ramayah, T., Faezah, J. N., \& Khalid, W. (2020). Green human resource management for organisational citizenship behaviour towards the environment and environmental performance on a university campus. Journal of Cleaner Production, 256, 1-13.

Appelbaum, E., Bailey, T., Berg, P., Kalleberg, A. L., \& Bailey, T. A. (2000). Manufacturing advantage: Why highperformance work systems pay off. Cornell University.

Arda, O. A., Bayraktar, E., \& Tatoglu, E. (2019). How do integrated quality and environmental management practices affect firm performance? Mediating roles of quality performance and environmental proactivity. Business Strategy and the Environment, 28(1), 64-78.

Arulrajah, A. A., Opatha, H. H. D. N. P., \& Nawaratne, N. N. J. (2016). Employee green performance of job: A systematic attempt towards measurement. Sri Lankan Journal of Human Resource Management, 6(1), 3762.

Athari, S. A., Alola, U. V., Ghasemi, M., \& Alola, A. A. (2020). The (un) sticky role of exchange and inflation rate in tourism development: Insight from the low and high political risk destinations. Current Issues in Tourism, 24(2), 1-16.

Baron, R. M., \& Kenny, D. A. (1986). The moderator-mediator variable distinction in social psychological research: Conceptual, strategic, and statistical considerations. Journal of Personality and Social Psychology, 51(6), 1173-1182.

Bhatti, S. H., Zakariya, R., Vrontis, D., Santoro, G., \& Christofi, M. (2020). High-performance work systems, innovation and knowledge sharing. Employee Relations: The International Journal, 43(2), 438-458.

Biscotti, A. M., D’Amico, E., \& Monge, F. (2018). Do environmental management systems affect the knowledge management process? The impact on the learning evolution and the relevance of organisational context. Journal of Knowledge Management, 22(3), 603-620.

Boiral, O., Baron, C., \& Gunnlaugson, O. (2014). Environmental leadership and consciousness development: A case study among Canadian SMEs. Journal of Business Ethics, 123(3), 363-383.

Boselie, P., Dietz, G., \& Boon, C. (2005). Commonalities and contradictions in HRM and performance research. Human Resource Management Journal, 15(3), 67-94.

Bos-Nehles, A. C., \& Veenendaal, A. A. (2019). Perceptions of HR practices and innovative work behavior: The moderating effect of an innovative climate. The International Journal of Human Resource Management, 30(18), 2661-2683.

Brettel, M., Chomik, C., \& Flatten, T. C. (2015). How organizational culture influences innovativeness, proactiveness, and risk-taking: Fostering entrepreneurial orientation in SMEs. Journal of Small Business Management, 53(4), 868-885. 
Cavicchi, C. (2017). Healthcare sustainability and the role of intellectual capital. Journal of Intellectual Capital, 18(3), 544-563.

Chang, C. H. (2011). The influence of corporate environmental ethics on competitive advantage: The mediation role of green innovation. Journal of Business Ethics, 104(3), 361-370.

Cheema, S., \& Javed, F. (2017). The effects of corporate social responsibility toward green human resource management: The mediating role of sustainable environment. Cogent Business \& Management, 4(1), 1-10.

Cobanoglu, C., Cavusoglu, M., \& Turktarhan, G. (2021). A beginner's guide and best practices for using crowdsourcing platforms for survey research: The case of Amazon Mechanical Turk (MTurk). Journal of Global Business Insights, 6(1), 92-97.

Daily, G. C., Polasky, S., Goldstein, J., Kareiva, P. M., Mooney, H. A., Pejchar, L., H Ricketts, T., Salzman, J., \& Shallenberger, R. (2009). Ecosystem services in decision making: Time to deliver. Frontiers in Ecology and the Environment, 7(1), 21-28.

Darnall, N., Jolley, G. J., \& Handfield, R. (2008). Environmental management systems and green supply chain management: Complements for sustainability? Business Strategy and the Environment, 17(1), 30-45.

Das, P., Verburg, R., Verbraeck, A., \& Bonebakker, L. (2018). Barriers to innovation within large financial services firms. European Journal of Innovation Management, 21(1), 96-112.

Davis, C. H. (1995). The earth summit and the promotion of environmentally sound industrial innovation in developing countries. Knowledge and Policy, 8(2), 26-52.

Dubey, R., Gunasekaran, A., Papadopoulos, T., \& Childe, S. J. (2015). Green supply chain management enablers: Mixed methods research. Sustainable Production and Consumption, 4, 72-88.

Dumont, J., Shen, J., \& Deng, X. (2017). Effects of green HRM practices on employee workplace green behavior: The role of psychological green climate and employee green values. Human Resource Management, 56(4), 613-627.

Dutta, S., \& Lanvin, B. (2012). The global innovation index 2012. Stronger innovation linkages for global. INSEAD. https://www.researchgate.net/profile/Daniela-

Benavente/publication/262843179_Measuring_Innovation_Potential_and_Results/links/0c96053902833ac5 0f000000/Measuring-Innovation-Potential-and-Results.pdf

El-Kassar, A. N., \& Singh, S. K. (2019). Green innovation and organizational performance: The influence of big data and the moderating role of management commitment and HR practices. Technological Forecasting and Social Change, 144, 483-498.

Elsetouhi, A. M., Hammad, A. A., Nagm, A. E. A., \& Elbaz, A. M. (2018). Perceived leader behavioral integrity and employee voice in SMEs travel agents: The mediating role of empowering leader behaviors. Tourism Management, 65, 100-115.

Fayyazi, M., Shahbazmoradi, S., Afshar, Z., \& Shahbazmoradi, M. (2015). Investigating the barriers of the green human resource management implementation in oil industry. Management Science Letters, 5(1), 101-108.

Gholami, R., Watson, R. T., Hasan, H., Molla, A., \& Bjorn-Andersen, N. (2016). Information systems solutions for environmental sustainability: How can we do more? Journal of the Association for Information Systems, 17(8), 521-538.

Gursoy, D., \& Kendall, K. W. (2006). Hosting mega events: Modeling locals' support. Annals of Tourism Research, 33(3), 603-623.

Hadi, D. M., Irani, F., \& Gökmenoğlu, K. K. (2020). External determinants of the stock price performance of tourism, travel, and leisure firms: Evidence from the United States. International Journal of Hospitality \& Tourism Administration. Advance online publication. https://doi.org/10.1080/15256480.2020.1842838

Hadood, A. A. A., \& Irani, F. (2020). Impact of economic sentiment and economic policy uncertainty on travel and leisure stock return. Journal of Hospitality and Tourism Insights, 4(1), 98-120.

Hair Jr, J. F., Sarstedt, M., Hopkins, L., \& Kuppelwieser, V. G. (2014). Partial least squares structural equation modeling (PLS-SEM). European Business Review, 26(2), 106-121.

Hair, J. F., Risher, J. J., Sarstedt, M., \& Ringle, C. M. (2019). When to use and how to report the results of PLSSEM. European Business Review, 31(1), 2-24.

Henseler, J., Hubona, G., \& Ray, P. A. (2016). Using PLS path modeling in new technology research: Updated guidelines. Industrial Management \& Data Systems, 116(1), 2-20.

Irani, F., \& Rahimizhian, S. (2021). Exploring the association among intention to study abroad, destination brand awareness, WOM, and destination choice of international students of North Cyprus [Conference presentation]. The Conference on Managing Tourism Across Continents, Sarasota, FL, United States. 
Irani, F., Kılı̧, H., Rahimizhian., \& Alpler, N. (2020, April 2-4). Effect of green HR practices on employee environmental commitment through environmental sustainable engagement: Evidence from green hotels in Turkey [Conference presentation]. The Conference on Managing Tourism Across Continents, Eskisehir, Turkey.

Irani, F., Ozturen, A., \& Akhshik, A., (2021). Host-tourist interactions and residents' attitudes towards sustainable tourism development. In A. Decrop, A. Correia, A. Fyall, \& M. Kozak, (Eds.), Sustainable and collaborative tourism in a digital world (pp.122-140). Goodfellow.

Jabbour, C. J. C., \& Santos, F. C. A. (2008). The central role of human resource management in the search for sustainable organizations. The International Journal of Human Resource Management, 19(12), 2133-2154.

Jabbour, C. J. C., Sarkis, J., de Sousa Jabbour, A. B. L., Renwick, D. W. S., Singh, S. K., Grebinevych, O., Kruglianskas, I., \& Godinho Filho, M. (2019). Who is in charge? A review and a research agenda on the 'human side' of the circular economy. Journal of Cleaner Production, 222, 793-801.

Jackson, J. C., Sinnott, P. L., Marx, B. P., Murdoch, M., Sayer, N. A., Alvarez, J. M., Greevy, R.A., Schnurr, P.P., Friedmand, M.J., Shane, A.C., Owen, R. R., Keane, T.M., \& Speroff, T., (2011). Variation in practices and attitudes of clinicians assessing PTSD-related disability among veterans. Journal of Traumatic Stress, 24(5), 609-613.

Jimenez-Jimenez, D., \& Sanz-Valle, R. (2008). Could HRM support organizational innovation? The International Journal of Human Resource Management, 19(7), 1208-1221.

Kim, Y. J., Kim, W. G., Choi, H. M., \& Phetvaroon, K. (2019). The effect of green human resource management on hotel employees' eco-friendly behavior and environmental performance. International Journal of Hospitality Management, 76, 83-93.

Lengnick-Hall, M. L., Lengnick-Hall, C. A., Andrade, L. S., \& Drake, B. (2009). Strategic human resource management: The evolution of the field. Human Resource Management Review, 19(2), 64-85.

Leroy, H., Segers, J., Van Dierendonck, D., \& Den Hartog, D. (2018). Managing people in organizations: Integrating the study of HRM and leadership. Human Resource Management Review, 28(3), 249-257.

Lievens, F., 2015. Human resource management. Lannoo.

Longoni, A., \& Cagliano, R. (2018). Inclusive environmental disclosure practices and firm performance. International Journal of Operations \& Production Management, 38(9), 1815-1835.

Luu, T. T. (2019). Green human resource practices and organizational citizenship behavior for the environment: The roles of collective green crafting and environmentally specific servant leadership. Journal of Sustainable Tourism, 27(8), 1167-1196.

Marin-Garcia, J. A., \& Tomas, J. M. (2016). Deconstructing AMO framework: A systematic review. Intangible Capital, 12(4), 1040-1087.

Masri, H. A., \& Jaaron, A. A. (2017). Assessing green human resources management practices in Palestinian manufacturing context: An empirical study. Journal of Cleaner Production, 143, 474-489.

Mercan, S., Cain, L., Akkaya, K., Cebe, M., Uluagac, S., Alonso, M., \& Cobanoglu, C. (2020). Improving the service industry with hyper-connectivity: IoT in hospitality. International Journal of Contemporary Hospitality Management, 33(1), 243-262.

Mitchell, M. L., \& Jolley, J. M. (2012). Research design explained. Cengage Learning.

Nejati, M., Rabiei, S., \& Jabbour, C. J. C. (2017). Envisioning the invisible: Understanding the synergy between green human resource management and green supply chain management in manufacturing firms in Iran in light of the moderating effect of employees' resistance to change. Journal of Cleaner Production, 168, 163172.

Nunnally, J. C., \& Bernstein, I. H. (1994). Psychological theory. McGraw-Hill.

O'Donohue, W., \& Torugsa, N. (2016). The moderating effect of 'Green' HRM on the association between proactive environmental management and financial performance in small firms. The International Journal of Human Resource Management, 27(2), 239-261.

Ogbeibu, S., Emelifeonwu, J., Senadjki, A., Gaskin, J., \& Kaivo-oja, J. (2020). Technological turbulence and greening of team creativity, product innovation, and human resource management: Implications for sustainability. Journal of Cleaner Production, 244, 1-15.

Ozdemir, O., Kizildag, M., Dogru, T., \& Demirer, I. (2021). Corporate social responsibility and financial performance: Does board diversity matter? Journal of Global Business Insights, 6(2), 98-116.

Paillé, P., Chen, Y., Boiral, O., \& Jin, J. (2014). The impact of human resource management on environmental performance: An employee-level study. Journal of Business Ethics, 121(3), 451-466.

Palmer, C., Niemand, T., Stöckmann, C., Kraus, S., \& Kailer, N. (2019). The interplay of entrepreneurial orientation and psychological traits in explaining firm performance. Journal of Business Research, 94, 183-194. 
Panwar, N. L., Kaushik, S. C., \& Kothari, S. (2011). Role of renewable energy sources in environmental protection: A review. Renewable and Sustainable Energy Reviews, 15(3), 1513-1524.

Parameswaran, R., \& Yaprak, A. (1987). A cross-national comparison of consumer research measures. Journal of International Business Studies, 18(1), 35-49.

Park, H. J., \& Park, E. (2020). How to enhance tourist perceptions of environmental issues through nature images: An importance-performance analysis. Journal of Global Business Insights, 5(2), 120-133.

Pham, N. T., Thanh, T. V., Tučková, Z., \& Thuy, V. T. N. (2020). The role of green human resource management in driving hotel's environmental performance: Interaction and mediation analysis. International Journal of Hospitality Management, 88, 1-10.

Pham, N. T., Tučková, Z., \& Jabbour, C. J. C. (2019). Greening the hospitality industry: How do green human resource management practices influence organizational citizenship behavior in hotels? A mixed-methods study. Tourism Management, 72, 386-399.

Pinzone, M., Guerci, M., Lettieri, E., \& Redman, T. (2016). Progressing in the change journey towards sustainability in healthcare: The role of 'Green'HRM. Journal of Cleaner Production, 122, 201-211.

Podsakoff, P. M., MacKenzie, S. B., Lee, J. Y., \& Podsakoff, N. P. (2003). Common method biases in behavioral research: A critical review of the literature and recommended remedies. Journal of Applied Psychology, $88(5), 879$.

Qi, G. Y., Shen, L. Y., Zeng, S. X., \& Jorge, O. J. (2010). The drivers for contractors' green innovation: An industry perspective. Journal of Cleaner Production, 18(14), 1358-1365.

Ragas, S. F. P., Tantay, F. M. A., Chua, L. J. C., \& Sunio, C. M. C. (2017). Green lifestyle moderates GHRM's impact on job performance. International Journal of Productivity and Performance Management, 66(7), 857-872.

Rahimizhian, S., \& Irani, F. (2020). Contactless hospitality in a post-Covid-19 world. International Hospitality Review. 1-12.

Ren, M., Zeng, W., Yang, B., \& Urtasun, R. (2018, July 10-15). Learning to reweight examples for robust deep learning [Conference presentation]. 35th International Conference on Machine Learning, Stockholm, Sweden.

Renwick, D. W., Redman, T., \& Maguire, S. (2013). Green human resource management: A review and research agenda. International Journal of Management Reviews, 15(1), 1-14.

Roos, G., \& O'Connor, A. (2015). Integrating innovation: South Australian entrepreneurship systems and strategies. University of Adelaide.

Roscoe, S., Subramanian, N., Jabbour, C. J., \& Chong, T. (2019). Green human resource management and the enablers of green organisational culture: Enhancing a firm's environmental performance for sustainable development. Business Strategy and the Environment, 28(5), 737-749.

Routroy, S. (2009). Antecedents and drivers for green supply chain management implementation in manufacturing environment. ICFAI Journal of Supply Chain Management, 6(1), 20-35.

Rusinko, C. (2007). Green manufacturing: An evaluation of environmentally sustainable manufacturing practices and their impact on competitive outcomes. IEEE Transactions on Engineering Management, 54(3), 445454.

Russo, M. V. (2009). Explaining the impact of ISO 14001 on emission performance: A dynamic capabilities perspective on process and learning. Business Strategy and the Environment, 18(5), 307-319.

Schaufeli, W. B., Bakker, A. B., \& Salanova, M. (2006). The measurement of work engagement with a short questionnaire: A cross-national study. Educational and Psychological Measurement, 66(4), 701-716.

Schiederig, T., Tietze, F., \& Herstatt, C. (2012). Green innovation in technology and innovation management-An exploratory literature review. R\&D Management, 42(2), 180-192.

Shafaei, A., Nejati, M., \& Yusoff, Y. M. (2020). Green human resource management. International Journal of Manpower, 41(7), 1041-1060.

Sheopuri, A., \& Sheopuri, A. (2015). Green HR practices in the changing workplace. Business Dimensions, 2(1), 1326.

Singh, S. K., \& El-Kassar, A. N. (2019). Role of big data analytics in developing sustainable capabilities. Journal of Cleaner Production, 213, 1264-1273.

Singh, S. K., Chen, J., Del Giudice, M., \& El-Kassar, A. N. (2019). Environmental ethics, environmental performance, and competitive advantage: Role of environmental training. Technological Forecasting and Social Change, 146, 203-211. 
Singh, S. K., Del Giudice, M., Chierici, R., \& Graziano, D. (2020). Green innovation and environmental performance: The role of green transformational leadership and green human resource management. Technological Forecasting and Social Change, 150, 1-12.

Sudin, S. K., Del Giudice, M., Chierici, R., \& Graziano, D. (2020). Green innovation and environmental performance: The role of green transformational leadership and green human resource management. Technological Forecasting and Social Change, 150, 1-12.

Teece, D. J. (2014). The foundations of enterprise performance: Dynamic and ordinary capabilities in an (economic) theory of firms. Academy of Management Perspectives, 28(4), 328-352.

Teixeira, A. A., Jabbour, C. J. C., de Sousa Jabbour, A. B. L., Latan, H., \& De Oliveira, J. H. C. (2016). Green training and green supply chain management: Evidence from Brazilian firms. Journal of Cleaner Production, 116, 170-176.

Temminck, E., Mearns, K., \& Fruhen, L. (2015). Motivating employees towards sustainable behaviour. Business Strategy and the Environment, 24(6), 402-412.

Tremblay, M. S., Colley, R. C., Saunders, T. J., Healy, G. N., \& Owen, N. (2010). Physiological and health implications of a sedentary lifestyle. Applied Physiology, Nutrition, and Metabolism, 35(6), 725-740.

Umrani, W. A., Channa, N. A., Yousaf, A., Ahmed, U., Pahi, M. H., \& Ramayah, T. (2020). Greening the workforce to achieve environmental performance in hotel industry: A serial mediation model. Journal of Hospitality and Tourism Management, 44, 50-60.

UNWTO. (2020). International tourism faces deepest crisis in history. UNWTO World Tourism Barometer, 18(2), 148. https://www.e-unwto.org/doi/epdf/10.18111/wtobarometereng.2020.18.1.2

Vidal-Salazar, M. D., Cordón-Pozo, E., \& Ferrón-Vilchez, V. (2012). Human resource management and developing proactive environmental strategies: The influence of environmental training and organizational learning. Human Resource Management, 51(6), 905-934.

Wei, M., Ku, T. Y., \& Liao, K. Y. H. (2011). Minority stress and college persistence attitudes among African American, Asian American, and Latino students: Perception of university environment as a mediator. Cultural Diversity and Ethnic Minority Psychology, 17(2), 195-203.

Weng, H. H. R., Chen, J. S., \& Chen, P. C. (2015). Effects of green innovation on environmental and corporate performance: A stakeholder perspective. Sustainability, 7(5), 4997-5026.

Yin, H., \& Schmeidler, P. J. (2009). Why do standardized ISO 14001 environmental management systems lead to heterogeneous environmental outcomes? Business Strategy and the Environment, 18(7), 469-486.

Yong, J. Y., Yusliza, M. Y., Jabbour, C. J. C., \& Ahmad, N. H. (2019). Exploratory cases on the interplay between green human resource management and advanced green manufacturing in light of the ability-motivationopportunity theory. Journal of Management Development, 39(1), 31-49.

Yu, W., Chavez, R., Feng, M., Wong, C. Y., \& Fynes, B. (2020). Green human resource management and environmental cooperation: An ability-motivation-opportunity and contingency perspective. International Journal of Production Economics, 219, 224-235.

Yu, W., Ramanathan, R., \& Nath, P. (2017). Environmental pressures and performance: An analysis of the roles of environmental innovation strategy and marketing capability. Technological Forecasting and Social Change, 117, 160-169.

Yusoff, Y. M., Nejati, M., Kee, D. M. H., \& Amran, A. (2020). Linking green human resource management practices to environmental performance in hotel industry. Global Business Review, 21(3), 663-680. 